\title{
A serological survey of brucellosis in wildlife in four major National Parks of Uganda
}

\author{
Robert Aruho ${ }^{1,2^{*}}$, Ewan T. MacLeod ${ }^{2}$, Leonard Manirakiza ${ }^{3}$ and Innocent B. Rwego ${ }^{4,5^{*}}$ (D)
}

\begin{abstract}
Background: Brucellosis is a contagious zoonotic disease of great public health and economic significance especially in developing countries. The disease affects humans and several species of livestock and wildlife. Studies on Brucellosis in wildlife in Uganda have been limited to single populations particularly in Queen Elizabeth National Park. This study aimed at estimating the percentage of positive samples of Brucella spp. in wildlife in four major national parks of Uganda. This was a retrospective survey which utilized archived samples collected from wildlife during the annual disease surveillance activities between 2013 and 2017.

Results: A total of 241 samples from seven species namely African buffalo (Syncerus caffer, $n=109$ ), African elephant (Loxodonta africana, $n=22$ ), giraffe (Giraffa camelopardalis rothschildi, $n=41$ ), Uganda kob (Kobus kob thomasi, $n=36$ ), lion (Panthera leo, $n=6$ ), plain zebra (Equus quagga, $n=25$ ), and bushbuck (Tragelaphus scriptus, $n$ $=2$ ), were tested for antibodies using the Rose Bengal Plate Test. The overall percentage of positive samples in the four national parks was 31.1\% (75/241; 95\% Cl: 25.6-37.2). Kidepo Valley National Park had a significantly higher percentage of positive samples of 55.9\% (19/34; 95\% Cl: 39.5-71.1) compared to other sampled national parks ( $p<$ 0.05). Lions had significantly higher percentage of positive samples at $66.7 \%$ (4/6) than African buffalo at $48.6 \%$ (53/ 109, $p$ < 0.0001). There were no antibodies for Brucella spp. detected in African elephant and bushbuck.
\end{abstract}

Conclusion: This study shows variations in percentage of positive samples with Brucella spp. between species and across national parks and notably a high percentage with Brucella spp. in wildlife in Uganda than that recorded elsewhere in sub-Saharan region of Africa. Potential for transmission to other wildlife and spill over to livestock is high especially in national parks with high livestock-wildlife interaction.

Keywords: Infectious diseases, Zoonoses, Buffaloes, Giraffe, Zebra, Lions, Elephants

\footnotetext{
*Correspondence: robertaruho@gmail.com; irwego@covab.mak.ac.ug; rwegovet@gmail.com

'Uganda Wildlife Authority (UWA) Headquarters, Plot 7, Kira Road, Kamwokya,

P. O Box 3530, Kampala, Uganda

${ }^{4}$ Department of Biosecurity Ecosystem and Veterinary Public Health, Africa One Health University Network (AFROHUN), College of Veterinary Medicine, Animal Resources and Biosecurity (COVAB), Makerere University, Box 7062, Kampala, Uganda

Full list of author information is available at the end of the article
}

(c) The Author(s). 2021 Open Access This article is licensed under a Creative Commons Attribution 4.0 International License, which permits use, sharing, adaptation, distribution and reproduction in any medium or format, as long as you give appropriate credit to the original author(s) and the source, provide a link to the Creative Commons licence, and indicate if changes were made. The images or other third party material in this article are included in the article's Creative Commons licence, unless indicated otherwise in a credit line to the material. If material is not included in the article's Creative Commons licence and your intended use is not permitted by statutory regulation or exceeds the permitted use, you will need to obtain permission directly from the copyright holder. To view a copy of this licence, visit http://creativecommons.org/licenses/by/4.0/ The Creative Commons Public Domain Dedication waiver (http://creativecommons.org/publicdomain/zero/1.0/) applies to the data made available in this article, unless otherwise stated in a credit line to the data. 


\section{Background}

Globally, brucellosis ranks among the top ten diseases at the wildlife-livestock interface and affects a wide range of species of wildlife. Cases of human and animal brucellosis have been recorded on almost all the continents [1]. Many scholars argue that wildlife are potential reservoirs for brucellosis and a potential source of infection to livestock. However, the role of wildlife in the epidemiology of brucellosis is not clear. A study conducted in Spain showed that when brucellosis is reduced in the livestock, it is also reduced in wildlife, implying that wildlife may not be actual reservoirs of infection [2].

Currently, there is a great concern about emerging diseases at wildlife-livestock interfaces. Research shows that $70 \%$ of emerging zoonotic diseases originate from wildlife [3], for example, Ebola, Marburg and recently Zika virus [4-7]. It is increasingly clear there is need to generate more information on important but neglected zoonotic diseases such as brucellosis in Uganda. An assessment by International Livestock and Research Institute (ILRI) [8] has identified brucellosis among the top 13 zoonoses that highly impact the poor communities in subSaharan Africa. This assessment identified Uganda, among other countries, with a high burden of brucellosis.

Across sub-Saharan Africa, brucellosis is highly prevalent in both wildlife and livestock [9]. A study by Waghela and Karstad [10] in Masai Mara wildlife reserve in Kenya found the prevalence of brucellosis of $18 \%$ and $31 \%$ in wildebeest and African buffaloes respectively. In a study conducted across five game parks in Zimbabwe, a seroprevalence rate of $17 \%$ for brucellosis was found in buffaloes [11]. The same study showed that seropositivity was higher in wildlife sampled at the interface with livestock. Assenga et al [12] and Waghela and Karstad [10] predicted that there could be transmission at the interface in such scenarios. There is a risk of Brucella transmission from wildlife to humans in sub-Saharan Africa due to bushmeat acquisition and consumption. For instance, it was found that bushmeat is a potential source of brucellosis for humans and that buffalo meat is the preferred source of bushmeat in Botswana [13]. With seroprevalence in buffaloes being $6 \%$ in Botswana, this could be a great risk to humans [13].

A few studies conducted in Uganda on brucellosis have concentrated on studying infection in livestock and humans [14-18]. To our knowledge, there have not been any studies published from national parks and wildlife areas in Uganda except for a single study by KalemaZikusoka et al. [19]. This study estimated the prevalence of brucellosis in African buffaloes in Queen Elizabeth National Park to be 2\%. Studies conducted around Lake Mburo National Park have indicated a high seropositivity of $55.6 \%$ and $31.8 \%$ in cattle and humans respectively $[14,20]$. Unlike in southern African countries where hunting for wild game is legal under certain circumstances, in Uganda bushmeat acquisition and consumption is illegal [21]. Despite strong law enforcement mechanisms, sometimes poachers succeed in their hunt for bushmeat which they then distribute through the 'black markets' along major transit routes disguised as livestock meat [22]. The illegality of acquisition and informal entry into the human food chains does not allow public health inspection of bushmeat in Uganda. The wildlife-livestock interface has been expanding as people continue to settle near wildlife protected areas in search of fresh water, pasture for livestock and fertile soils to support food production. According to the study by Godfroid et al. [23] such close wildlife-livestock interfaces provide potential opportunities for transmission and persistence of infection of brucellosis in populations. Brucellosis is endemic throughout the country with individual animal prevalence of $15.8 \%$ in south western Uganda, $5.1 \%$ in central Uganda, and $7.5 \%$ in northern Uganda [17, 20, 24].

The increasing human populations and concomitant insatiable demand for food has caused tremendous changes in husbandry such as intensification of agriculture [25]. The quest for more arable land for large scale commercial farming is pushing people and livestock closer to wildlife protected areas in Uganda. At the park boundaries, there is a mix of wildlife, livestock and humans as they compete for scarce resources. Sharing of resources such as food, grazing land, and water at the same time between wildlife, livestock and humans has become common resulting in human-wildlife conflict and an opportunity for disease transmission and spread of zoonotic diseases such as Brucella spp. [26]. Despite presence of facilities and expertise to study Brucellosis in Uganda, no studies have been conducted in wildlife involving more than one national park. This study was, therefore, undertaken to estimate the percentage of positive samples with Brucella spp. in wildlife in four major national parks of Uganda.

\section{Results}

A total of 241 wildlife samples from four selected national parks of Uganda were analyzed for Brucella positivity. Wildlife samples analyzed came from buffaloes $(n$ $=109,45.2 \%)$, bushbucks $(n=2,0.8 \%)$, elephants $(n=$ $22,9.1 \%)$, giraffe $(n=41,17 \%)$, lions $(n=6,2.5 \%)$, Uganda kob $(n=36,14.9 \%)$ and zebras $(n=25,10.4 \%)$.

\section{Percentage of Brucella positive samples at national park level}

Lions showed the highest overall percentage of positive samples of $66.7 \%$ (Fig. 1), although they were only sampled from Kidepo Valley National Park (Fig. 2). Buffaloes showed second highest percentage of positive samples (48.6\%) overall, and with the exception of lions 


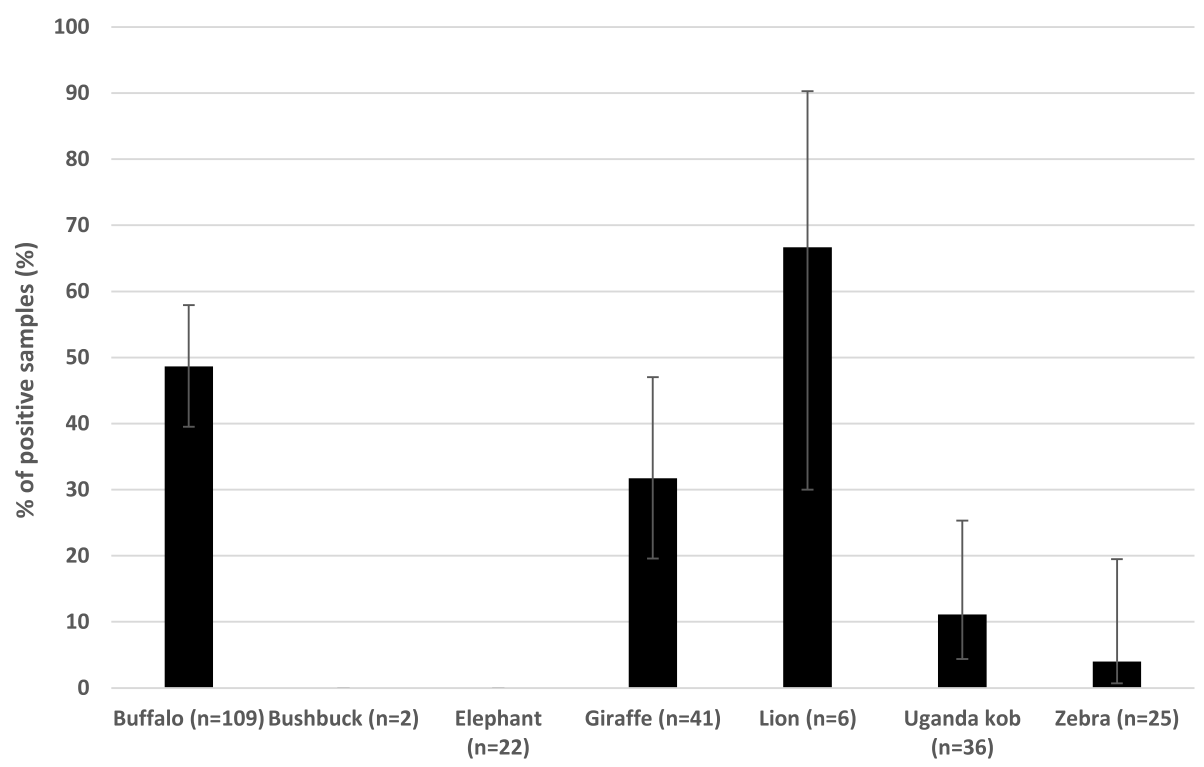

Fig. 1 Percentage of Brucella positive samples in different wildlife species in selected Ugandan National parks

in Kidepo Valley National Park, showed the highest percentage of Brucella positive samples in each of the other national parks (Fig. 2). The overall percentage of positive samples in the four national parks was 31.1\% (75/241; 95\% CI: 25.6-37.2). Percentage of positive samples at national park level showed Kidepo Valley National Park had the highest percentage and Lake Mburo National Park had the lowest (Table 1). In addition, Kidepo Valley National Park had a significantly higher percentage of brucellosis compared to all other national parks $(p<0.05)$.
Overall, there was significant differences in percentage of positive samples in the national parks (G-Statistic $=-$ $0.495, p<0.0001)$. The percentage positive samples in Lake Mburo National Park was significantly lower than that of Kidepo Valley National Park $(p<0.0001$; Table 1). In addition, percentage of brucellosis in Kidepo Valley National Park was significantly higher than that in the other three national parks (Table 1).

There were differences in percentage of positive samples of Brucella among the different animal species that

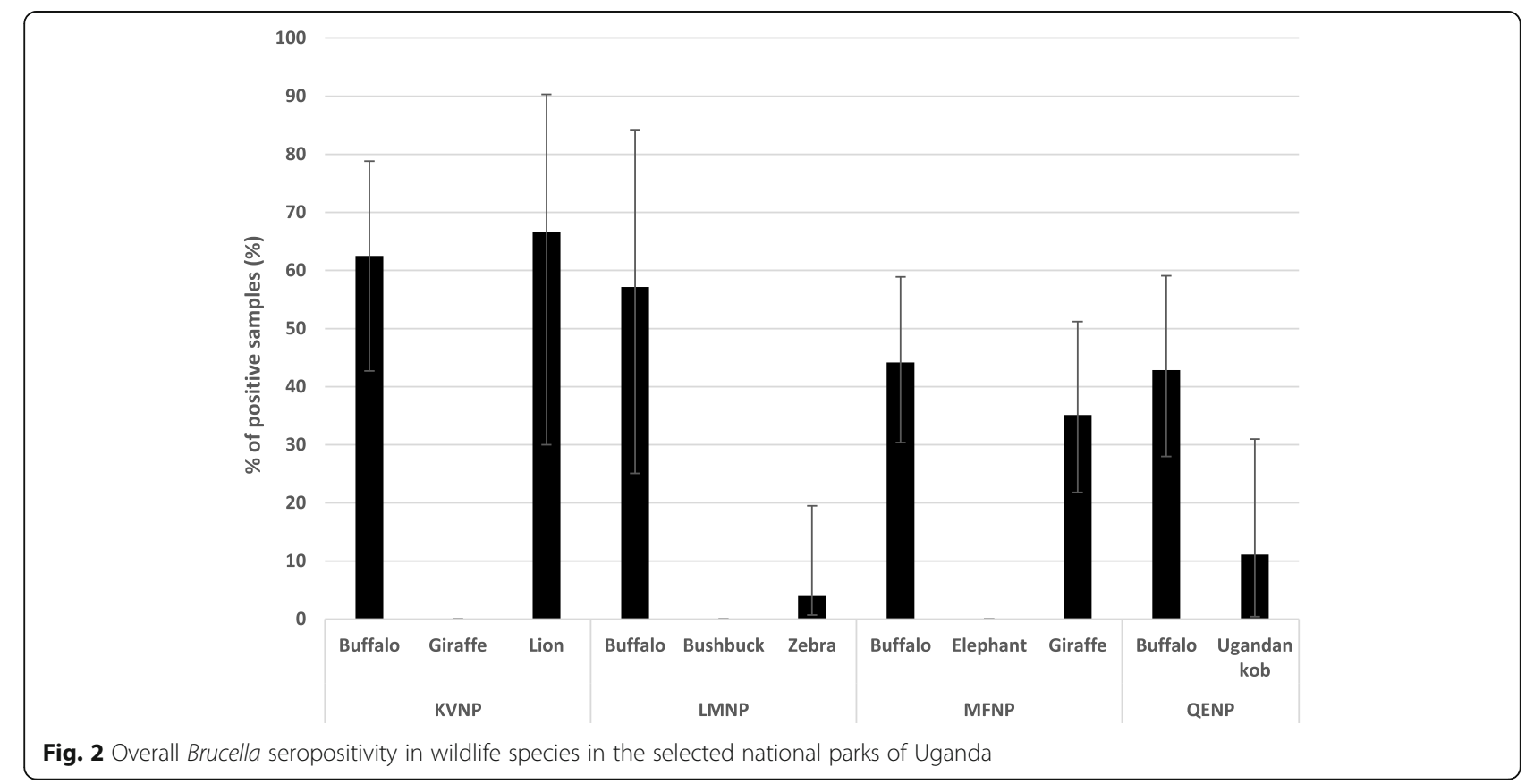


Table 1 Percentage of Brucella spp. Positive Samples in Four Major National Parks of Uganda

\begin{tabular}{|c|c|c|c|c|c|c|}
\hline $\begin{array}{l}\text { National } \\
\text { Parks }\end{array}$ & $\begin{array}{l}\text { No. of } \\
\text { samples } \\
\text { tested per } \\
\text { National Park }\end{array}$ & $\begin{array}{l}\% \text { of } \\
\text { positive } \\
\text { samples } \\
\text { per } \\
\text { National } \\
\text { Park }\end{array}$ & $95 \% \mathrm{Cl}$ & $\begin{array}{l}\text { Inter-Park comparisons } \\
\text { Comparison Park }\end{array}$ & $\begin{array}{l}\text { Z- } \\
\text { Statistic }\end{array}$ & $P$-Value \\
\hline \multirow[t]{3}{*}{ KVNP } & 34 & 55.9 & $39.5-71.1$ & LMNP & 6.78 & $<0.0001^{* *}$ \\
\hline & & & & QENP & 3.83 & $0.0001^{* *}$ \\
\hline & & & & MFNP & 3.08 & $0.001^{* *}$ \\
\hline \multirow[t]{3}{*}{ LMNP } & 34 & 14.7 & $6.5-30.1$ & QENP & -1.59 & 0.944 \\
\hline & & & & MFNP & -2.10 & 0.982 \\
\hline & & & & KVNP & -4.84 & $<0.0001^{* *}$ \\
\hline \multirow[t]{2}{*}{ QENP } & 71 & 26.8 & 17.9-38.1 & MFNP & -0.835 & 0.798 \\
\hline & & & & KVNP & -4.94 & $<0.0001^{* *}$ \\
\hline MFNP & 102 & 31.4 & $23.2-40.9$ & KVNP & -4.98 & $<0.0001^{* *}$ \\
\hline
\end{tabular}

KVNP Kidepo Valley National Park, LMNP Lake Mburo National Park, QENP Queen Elizabeth National Park, MFNP Murchison Falls National Park

were tested (G-statistic $=-0.659, p<0.0001)$. The percentage of positive samples of Brucella in lions was significantly higher than that in buffaloes $(p<0.0001)$. The percentage of positive samples of Brucella in zebras was significantly lower from that of buffaloes $(p<0.0001)$, and lions $(p<0.0001)$ and giraffe $(p<0.0015$, Table 2$)$. The percentage of positive samples in Uganda kob was significantly lower than that from buffaloes $(p=0.001)$, lions $(p=0.003)$ and giraffe $(p=0.004)$.
Discussion

This was the first study looking at percentage of Brucella spp. positive samples in wildlife involving more than one national park in Uganda. In this study, the overall percentage of positive Brucella samples was $31.1 \%$ in the four major national parks. This is higher than the percentage of $2 \%$ recorded in wildlife in Queen Elizabeth National Park [19]. The percentage in wildlife in this current study is also higher than that recorded in

Table 2 Inter-species Brucellosis Multiple Comparison

\begin{tabular}{|c|c|c|c|c|}
\hline Base species ( $P r=\%$ of + ve samples) & Comparison species & $\%$ of positive samples & G-Statistic & $p$-value \\
\hline \multirow[t]{6}{*}{ Zebra $\left(P r^{*}=4.0\right)$} & Uganda Kob & 11.1 & -1.13 & 0.87 \\
\hline & Bush buck & 0.0 & - & - \\
\hline & Buffaloes & 48.6 & -4.46 & $<0.0001^{* *}$ \\
\hline & Lion & 66.7 & -6.65 & $<0.0001^{* *}$ \\
\hline & Giraffes & 31.7 & -2.98 & $0.0015^{* *}$ \\
\hline & Elephant & 0.0 & - & - \\
\hline \multirow[t]{5}{*}{ Uganda Kob $(\operatorname{Pr}=11.1)$} & Bush buck & 0.0 & - & - \\
\hline & Buffaloes & 48.6 & -4.80 & $<0.0001^{* *}$ \\
\hline & Lion & 66.7 & -7.08 & $<0.0001^{* *}$ \\
\hline & Giraffes & 31.7 & -2.66 & $0.004^{* *}$ \\
\hline & Elephant & 0.0 & - & - \\
\hline \multirow[t]{3}{*}{ Buffaloes ( $P r=48.6)$} & Lion & 66.7 & -4.01 & $<0.0001^{* *}$ \\
\hline & Giraffes & 31.7 & 3.79 & $0.0001^{* *}$ \\
\hline & Elephant & 0.0 & - & - \\
\hline \multirow[t]{2}{*}{ Lion $(P r=66.7)$} & Giraffes & 31.7 & 1.84 & $0.033^{* *}$ \\
\hline & Elephant & 0.0 & - & - \\
\hline Giraffe $(P r=31.7)$ & Elephant & 0.0 & - & - \\
\hline
\end{tabular}

$\operatorname{Pr}=\%$ of positive samples; $+v e=$ Positive 
livestock in Uganda [17, 20]. What is interesting in this study is that parks such as Kidepo Valley National Park, and Murchison Falls National Park that have relatively low livestock-wildlife interaction had far higher percentage of positive samples than Lake Mburo and Queen Elizabeth National Parks which have a very close livestock-wildlife interaction.

Among the national parks studied, Kidepo Valley National Park had the highest percentage of positive samples at $55.9 \%$. This percentage is higher than the $9.2 \%$ recorded in cattle in Karamoja where the national park is situated [27]. It is not clear what the source of brucellosis in Kidepo National Park may be. The park is located in north east Uganda, a very remote area that has been characterized by insecurity for a long time [28]. There is less information available on the disease burden for the region. The veterinary extension services in the region have been almost non-existent with people relying on ethno-medicine to control cattle diseases [29]. Frequent cattle incursion in the park, especially during long dry spells, in search of water and pasture is a big opportunity for sustained infection in wildlife and cattle. It is therefore not surprising to find that a disease like brucellosis may have found a suitable niche. According Serrano et al. [2], brucellosis is well maintained in wildlife when interventions to control the disease in livestock are poor. Areas around Kidepo Valley and Murchison Falls National Parks have been recovering from the effects of Lords Resistance Army war which hindered agricultural extension services delivery in the region [30]. Although the percentage of positive samples in wildlife is higher than in cattle in the areas surrounding these national parks $[17,20]$, the direction of spread of brucellosis across wildlife and livestock is not clear and needs to be investigated. We did not detect any positives in the elephant or bushbuck samples, this agrees with previous studies that have not detected brucellosis in these animals [13].

The buffaloes in the four national parks sampled in Uganda had high percentage of positive samples of $48.6 \%$ compared to the $2 \%$ previously reported by Kalema-Zikusoka et al. [19] in Queen Elizabeth National Park. The rise in percentage of positive samples could be due to increased interactions with cattle infected with brucellosis at the wildlife interface. However, as percentage of positive samples did not vary much between the four national parks, and there were differences between the national parks in terms of cattle interaction, this could suggest that buffaloes play a role as a reservoir species. These findings are consistent with results from other studies conducted elsewhere in east and southern Africa by Motsi et al. [11], Alexander et al. [13], and Waghela and Karstad [10] that showed a higher percentage in wildlife. It is believed that buffaloes harbor
Brucella better than other species for reasons not well understood [11]. Buffaloes are gregarious animals and usually live in big herds. Herd size has a big effect on the transmission of brucellosis [31]. According to Dobson and Meagher [31], brucellosis is well maintained in herd sizes of greater than 200 individual animals per herd. The disease prevalence tends to be high in big herds because the small inter-animal distance helps to sustain transmission by contact [32]. Therefore, herd sizes like those in Kidepo National Park (around 6900 buffaloes) are likely to maintain infection for a very long time without showing any impact on the population.

Four out of six lions sampled were positive. This was the highest percentage of positive samples of all the wildlife in this study. However, it is difficult to conclude if this is representative of Brucella infection in lions due to the small sample size tested in the current study. They have been few previous studies investigating $\mathrm{Bru}$ cella seropositivity in lions. However, a study in Tanzania did find one positive lion out of two tested [12]. During field sample collection for the current study, one typical clinical case of brucellosis in lions was encountered. The affected lion had hygroma around joints and was always reluctant to move (Robert Aruho, Personal observation). This lion was positive for Brucella spp in this study. From the observations in the field, lions usually choose prey on which they will not spend a lot of energy to hunt. Clinically, sick animals affected by brucellosis usually develop mobility challenges because of dysfunctional joints and usually tend to move behind the herds. This makes the animals, such as buffaloes, easy prey by predators especially the lions which thrive best at hunting solitary prey [33]. Lions might also seroconvert due to exposure to Brucella through feeding on such infected animals. Previous work had shown that lions may become immune to Trypanosoma brucei rhodesiense infections due to being exposed to parasites through consumption of infected meat [34]. Such a scenario could be responsible for high percentage of Brucella spp. positive samples in lions of Kidepo Valley National Park. According to Uganda Wildlife Authority in 2018, the lion population in Kidepo Valley National Park was about 132 individuals. We tested a few individuals compared to the population size. Therefore, this calls for more studies to be undertaken in this lion population of Kidepo Valley National Park and other national parks to determine the extent of infection and its impact on lion populations.

This is the first study of Brucella in Uganda kob. The percentage of positive samples in Uganda kob (11.1\%) was higher than that observed in other medium sized antelopes such as impala (1.4\%) in similar ranging conditions in Zimbabwe [11] and black lechwe (Kobus leche smithemani) (0\%) in Zambia [35]. The percentage in the 
Uganda kob was lower than that found in Kafue lechwe (Kobus leche kafuensis) which was estimated at $42.9 \%$ [35]. In this case, the higher prevalence in the Kafue lechwe was related to interaction with positive cattle and infection might now be endemic within the antelope population. Positives in Uganda kob could be due to fact that Uganda kob are found in areas where they are likely to interact with livestock. Uganda kob are most likely to be taken for bushmeat. In Uganda, bushmeat consumption especially along major transit routes is becoming a serious threat to public health [22]. However, there is insufficient data on the trends of bushmeat consumption in Uganda but studies within the East African region indicating increasing incidences of bushmeat consumption in East Africa with antelopes being the most preferred source of bushmeat [36, 37]. This high percentage observed in Uganda kob could result in several human cases of infection unless mitigation measures are put in place to deter entry of bushmeat into the human food chain.

Several studies have detected positives in African giraffe populations and in this study, giraffes had the third highest percentage of positive samples of $31.7 \%$. The percentage of positive samples in giraffes in Uganda is higher than in other African giraffe range states such as Botswana and Zimbabwe that had prevalence values of $11 \%$ and $3.7 \%$ respectively $[13,38]$. Although there is no evidence of bushmeat consumption of giraffe meat in Uganda, there has been a notable increase on the number of snaring cases of giraffes in Murchison Falls National Park [39]. In the majority of the cases, snaring in Uganda is closely associated with bushmeat consumption [40].

Brucellosis has been recorded in domestic equids as far as early 1970s. Study in wild equids have been very limited [41]. In our study only one out of the 25 tested zebra was positive (4\%). There have not been many studies investigating brucellosis in zebra. Assenga et al [12] found no positives in the two animals they sampled in Tanzania and Alexander et al. [13] found no positives in 21 zebras from Botswana. The only study where positives were found were in what was Rhodesia in the 1960 s, where $24 \%$ of 50 tested animals were positive [42].

Recently, the Uganda Wildlife Authority launched ambitious plans to restock several protected areas with wildlife especially with those species that are threatened or pose a considerable human-wildlife conflict $[43,44]$. Recently, Uganda translocated several giraffes from Murchison Falls National Park to Lake Mburo National Park and other areas [39, 45]. A study by Caron et al. [46] shows that movement of wildlife provides a conduit for the spread of disease to new susceptible populations. Therefore, interventions that involve movement of wildlife present a considerable risk of disease spread to other new areas [47]. This calls for regular screening of wildlife before undertaking translocations.

This study capitalized on using the archived wildlife samples that were already collected during the previous disease surveillance in the four major national parks. This affected the sample size and the sampling strategy that could be used to collect samples and therefore could have led to over- or under-estimating of the percentage of positive samples. Archived samples were used because the cost of sample collection in wildlife is prohibitive [48]. It involves purchase of immobilization drugs and requires experienced veterinary expertise to immobilize wildlife. Secondly, the ethical justification of the immobilization of wildlife to collect samples requires a lot of explanation because of the risk involved. Therefore, this may be one of the most available opportunities to determine percentage of positive samples in wildlife. All the national parks have some form of livestockwildlife interaction. However, this study did not determine the level of interaction, in which location and how the interaction occurs. These reasons limited this study to use only available archived samples. Therefore, the results of the study will apply only to those parks and species sampled. In future, as samples for study of brucellosis are being collected, concurrent samples could be collected from livestock. In addition, geographical position system could be used to collect information on location and possible interaction between wildlife and livestock.

In this study, we utilized Rose Bengal plate test (RBPT) to analyze percentage of positive samples in the wildlife samples. In African buffaloes the sensitivity and specificity of RBPT has been estimated as $98.6 \%$ and $99.2 \%$ respectively [49]. However, validation in other wildlife species has not been carried out. This may have led to some false positives and false negatives. Future studies should consider using more specific and sensitive tests such as polymerase chain reaction.

\section{Conclusion}

This study shows that the percentage of Brucella exposure is high in wildlife in the four major national parks of Uganda. African buffalo are the most affected species. Brucellosis has been listed among the class B bioterror agent [50] and listed also among the top five priority diseases in Uganda [51]. This study has shown that there is high percentage of Brucella positives in several Ugandan wildlife species and therefore, understanding the disease in wildlife will set a great foundation to its control and elimination especially at the human-livestock and wildlife interface. A lot of knowledge gaps remain in understanding the role wildlife plays in the epidemiology of 
brucellosis. The impact of the disease on wildlife also needs to be explored considering emerging issues such as climate change which seems to offer opportunity for emerging diseases. The impact that brucellosis has caused or is causing in wildlife in Uganda is not clear yet. What is clear is that the percentage of positive samples over the total tested is higher in wildlife than in livestock. It will be very interesting to conduct synchronized and systematic surveys for wildlife and livestock at Uganda major wildlife-livestock interface to better understand the role of wildlife and livestock in the epidemiology of brucellosis.

\section{Methods}

\section{The study area}

Uganda is a landlocked country which lies between longitudes $4.20^{\circ} \mathrm{N}$ and $1.20^{\circ} \mathrm{S}$, and latitude $29.5^{\circ} \mathrm{E}$, and $35^{\circ} \mathrm{W}$ [52]. The country is in a region where seven of the distinct bioregions converge. Given the location between ecological communities between east Africa drier grasslands and west African tropical rain forests, coupled with high altitude ranges, Uganda has a high level of biodiversity [52]. Uganda has 10 national parks and 12 game reserves. This study was conducted in four major grassland national parks in Uganda, including Queen
Elizabeth National Park (QENP), Lake Mburo National Park (LMNP), Murchison Falls National Park (MFNP) and Kidepo Valley National Park (KVNP) [Fig. 3]. These national parks have a high biodiversity and abundance of wildlife, and a very close wildlife-livestock interface. For instance, Lake Mburo and Queen Elizabeth National Parks have a very close wildlife-livestock interaction of the four parks selected with enclave human communities living in or around the parks with their livestock [43].

\section{Sample collection}

This study utilized a total of 241 samples that were collected by the Uganda Wildlife Authority Veterinary Unit during routine annual surveillance in the four national parks between years 2013 and 2017. Kidepo Valley National Park contributed most of the wildlife samples used for this study. Most of the wildlife samples were from African buffalo (Syncerus caffer) (Table 3). Samples were also collected from African elephants (Loxodonta africana), giraffes (Giraffa camelopardalis rothschildi), Uganda kobs (Kobus kob thomasi), lions (Panthera leo), plain zebras (Equus quagga) and bushbucks (Tragelaphus scriptus).

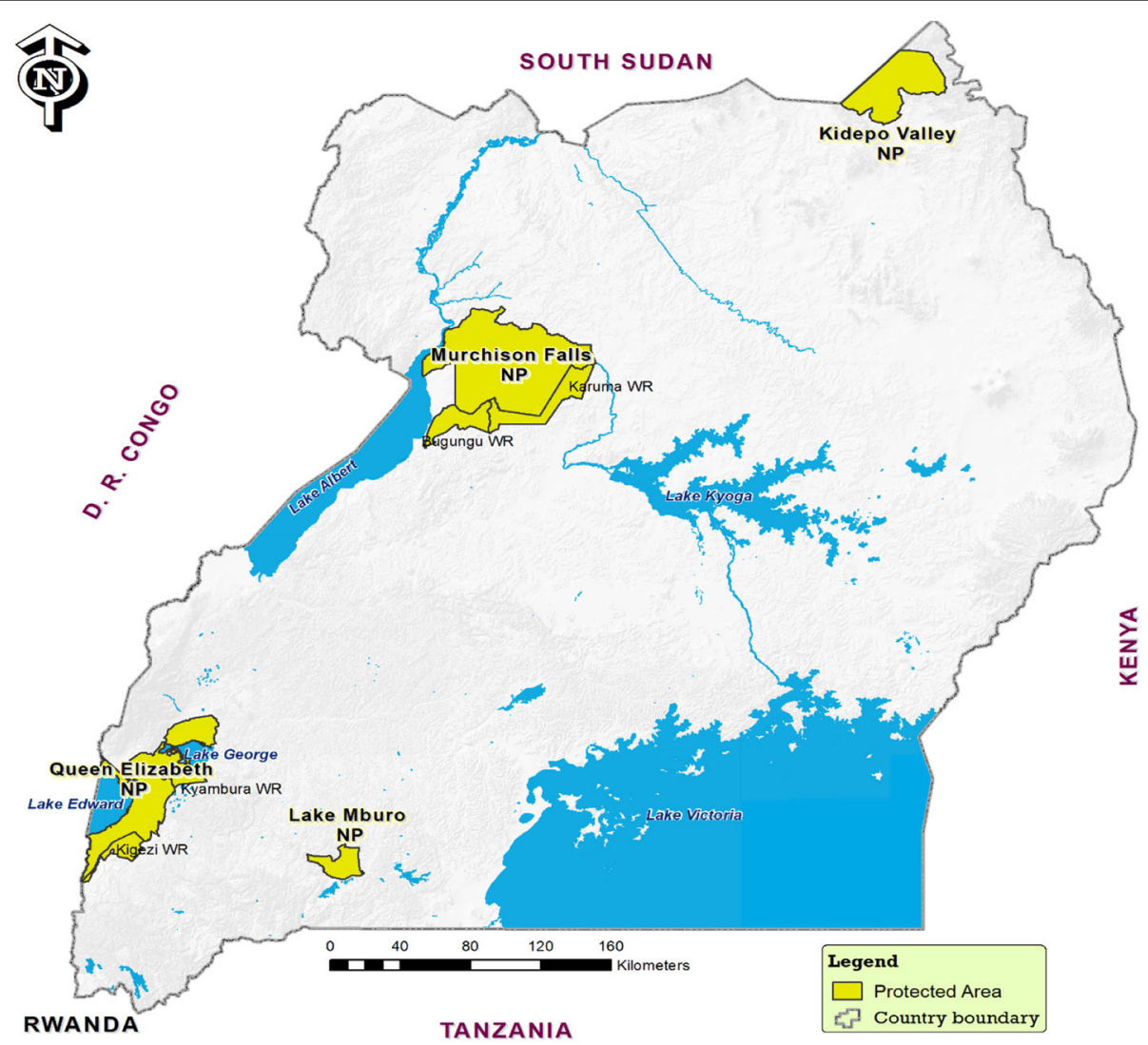

Fig. 3 Location of National Parks in Uganda where samples were collected for Brucellosis study (Source: Authors) 
Table 3 The number of different wildlife species sampled in four national parks of Uganda

\begin{tabular}{llllllll}
\hline $\begin{array}{l}\text { National } \\
\text { Park }\end{array}$ & \multicolumn{2}{l}{ No. of Samples for Each Species } & & & \\
\cline { 2 - 8 } & Uganda kobs & Lions & Buffaloes & Zebras & Elephants & Giraffes & Bush- bucks \\
\hline KVNP & 0 & 6 & 24 & 0 & 0 & 4 & 0 \\
MFNP & 0 & 0 & 43 & 0 & 22 & 37 & 0 \\
QENP & 36 & 0 & 35 & 0 & 0 & 0 & 2 \\
LMNP & 0 & 0 & 7 & 25 & 0 & 0 & 0 \\
Total & 36 & 6 & 109 & 25 & 22 & 41 & 2 \\
\hline
\end{tabular}

KVNP Kidepo Valley National Park, LMNP Lake Mburo National Park, MFNP Murchison Falls National Park, QENP Queen Elizabeth National Park

During the collection of blood samples, the wildlife were chemically immobilized following the Uganda Wildlife Authority standard veterinary protocol. Briefly, the animals to be sampled were selected randomly from a herd or group of animals. The sample size was not calculated because the population size was not known. Secondly, getting the rquired sample size reuires a significant amount of resources and lastly, the risk of an animal dying due to chemical immobilization is high. Once an animal was selected, it was immobilized using Etorphine Hydrochloride (Norvatis SA Ltd., Animal Health) at appropriate dose recommended for each species [53]. After sample collection, the effects of Etorphine were reversed by administering Diprenorphine hydrochloride (Norvatis SA Ltd., Animal Health) through the ear vein at twice the dose of Etorphine given. In the giraffes, the Etorphine effects were reversed with Naltrexone Hydrochloride at $20 \mathrm{mg}$ of Etorphine used through the jugular vein [54].

In all species, $5 \mathrm{ml}$ of blood were collected by venipuncture through the jugular vein. The blood in tubes was placed vertically in a rack and allowed to clot over night at room temperature. Serum was gently pipetted out into cryovials and placed in liquid nitrogen and transported to the Ministry of Agriculture, Animal Industry and Fisheries, National Animal Disease Diagnostic Centre, Entebbe, Uganda and stored at $-20^{\circ} \mathrm{C}$ pending laboratory analysis. All the animals were released back into their natural habitats near where they were immobilized from.

\section{Laboratory analysis}

The analysis was done according to the protocol for Rose Bengal plate test (RBPT) set by the World Health Organisation for Animal Health [55]. Briefly, the test procedure was as follows: the serum samples were removed from $-20{ }^{\circ} \mathrm{C}$ freezer and kept at $4{ }^{\circ} \mathrm{C}$ overnight to allow the serum to thaw. Samples were then sorted and all hemolyzed samples were removed and not included in the analysis. The sample vials were placed into a rack. Twenty-five microlitres of each sample was placed on a white tile and $25 \mu$ l of positive control added. Twenty-five microlitres of Rose Bengal reagent
(Onderstepoort Biological Products Pty, South Africa) was gently added to each of the samples. The samples and the reagent were gently mixed using an applicator stick in a circular manner. The tile was rocked for $4 \mathrm{~min}$ at room temperature. Observation was made for agglutination within $4 \mathrm{~min}$ and recorded. After reading the results, the tile was washed with distilled water and dried.

\section{Data analysis}

Initially all data was entered in Microsoft Excel v2016, sorted and checked for completeness. Data was exported to Statistical Package for the Social Sciences v20 for analysis. At bivariate level, data was summarized using frequencies and percentages. The percentage of positive samples of brucellosis was calculated by taking the number of infected animals as a percentage of total number of animals sampled per animal species and per national park. The percentage of positive samples of brucellosis was compared by species and by national park using Goodman and Kruskal's Gamma (G-test). The difference in percentage of positive samples of brucellosis was done using multiple comparison post-hoc of proportions and the G-statistics, together with their $p$-values, were reported. All the analysis was carried out at $95 \%$ CI and the variables with $P$-Values less than 0.05 were considered significant in this analysis.

\section{Abbreviations \\ AFROHUN: Africa One Health University Network; ANOVA: Analysis of variance; COVAB: College of Veterinary Medicine, Animal Resources and Biosecurity; ILRI: International Livestock and Research Institute; KVNP: Kidepo Valley National Park; LMNP: Lake Mburo National Park; MFNP: Murchison Falls National Park; NEMA: National Environmental Management Authority; OIE: World Organization for animal health; QENP: Queen Elizabeth National Park; RBPT: Rose bengal plate test; UK: United Kingdom; UNCST: Uganda National Science and Technology; UWA: Uganda Wildlife Authority; WCS: Wildlife Conservation Society}

\section{Acknowledgements}

We thank Uganda Wildlife Authority (UWA) and Uganda's Ministry of Agriculture, Animal Industry and Fisheries (MAAIF) National Animal Disease, Diagnostics and Epidemiology Centre (NADDEC) for allowing us access the archived wildlife samples and approving the study. In addition, we thank the UWA Wild life Veterinarians who have over the years collected samples from wildlife. 


\section{Authors' contributions}

RA and IBR conceived the study; RA was responsible for the study coordination, laboratory analysis and retrieving samples from the lab; RA, ETM, LM and IBR were responsible for data analysis and drafting of the manuscript; IBR provided the funding for laboratory analysis and was the supervisor for the Masters student work. All authors have read, edited and approved the manuscript.

\section{Funding}

The Commonwealth Scholarship Commission at the University of Edinburgh on the International Animal Health programme provided funding to conduct partial laboratory work. Uganda Wildlife Authority (UWA) funded collection of blood samples from wildlife. UWA's field veterinarians included RA who participated in collection of blood from wildlife. All the data analysis and partial laboratory work was funded by the International Research Development Center (IDRC) - Canada Ecohealth Chair Grant (Grant No. 107345-001) to Innocent B. Rwego at AFROHUN network.

\section{Availability of data and materials}

The samples used during the study are available upon request to UWA and Ministry of Agriculture Animal Industry and Fisheries National Disease Diagnostic and Epidemiology Centre and the relevant government of Uganda bodies ethical approval sought. The data used for analysis is all presented here. All the animals from which the blood samples were collected were released back into the wild.

\section{Ethics approval and consent to participate}

Before undertaking study, the proposal was submitted to Uganda Wildlife Authority (UWA) ethical review committee and approved under permit number: COD/96/02. The proposal and the sample collection protocol were then submitted to Uganda National Science and Technology (UNCST) and approved under permit number NS 587. As a requirement under United Kingdom laws (Animal Scientific procedures, 1986) about overseas studies involving animal subjects, the approval permits from Uganda and the proposal were submitted to the Animal Welfare and Ethical Review Body University of Edinburgh and the study was cleared under permit number: OS14-16.

\section{Consent for publication}

Not applicable.

\section{Competing interests}

The authors declare that they have no competing interests.

\section{Author details}

'Uganda Wildlife Authority (UWA) Headquarters, Plot 7, Kira Road, Kamwokya, P. O Box 3530, Kampala, Uganda. ${ }^{2}$ Division of Infection and Pathway Medicine, 1 George Square, Biomedical Sciences, Edinburgh Medical School, College of Medicine and Veterinary Medicine, The University of Edinburgh, Edinburgh EH8 9JZ, UK. ${ }^{3}$ National Pharmacovigilance Centre, Uganda National Drug Authority, Ministry of Health, Kampala, Uganda. ${ }^{4}$ Department of Biosecurity Ecosystem and Veterinary Public Health, Africa One Health University Network (AFROHUN), College of Veterinary Medicine, Animal Resources and Biosecurity (COVAB), Makerere University, Box 7062, Kampala, Uganda. ${ }^{5}$ Department of Veterinary Population Medicine, One Health Division, College of Veterinary Medicine, University of Minnesota, St. Paul, MN, USA.

Received: 25 March 2020 Accepted: 31 January 2021 Published online: 01 March 2021

\section{References}

1. Pappas G, Papadimitriou P, Akritidis N, Christou L, Tsianos EV. The new global map of human brucellosis. Lancet Infect Dis. 2006;6(2):91-9.

2. Serrano E, Cross PC, Beneria M, Ficapal A, Curia J, Marco X, et al. Decreasing prevalence of brucellosis in red deer through efforts to control disease in livestock. Epidemiol Infect. 2011;139(10):1626-30.

3. Bengis RG, Leighton FA, Fischer JR, Artois M, Mörner T, Tate CM. The role of wildlife in emerging and re-emerging zoonoses. Rev Sci Tech Int Off Epizoot. 2004 Aug;23(2):497-511.
4. Okware SI, Omaswa FG, Zaramba S, Opio A, Lutwama JJ, Kamugisha J, et al. An outbreak of Ebola in Uganda. Trop Med Int Health TM IH. 2002;7(12): 1068-75.

5. Lamunu M, Lutwama JJ, Kamugisha J, Opio A, Nambooze J, Ndayimirije N, et al. Containing a haemorrhagic fever epidemic: the Ebola experience in Uganda (October 2000-January 2001). Int J Infect Dis IJID Off Publ Int Soc Infect Dis. 2004;8(1):27-37.

6. Adjemian J, Farnon EC, Tschioko F, Wamala JF, Byaruhanga E, Bwire GS, et al. Outbreak of Marburg hemorrhagic fever among miners in Kamwenge and Ibanda Districts, Uganda, 2007. J Infect Dis. 2011;204(Suppl 3):S796-9.

7. Campos GS, Bandeira AC, Sardi SI. Zika Virus Outbreak, Bahia, Brazil. Emerg Infect Dis. 2015;21(10):1885-6.

8. Grace D, Mutua F, Ochungo P, Kruska RL, Jones K, Brierley L, et al. Mapping of poverty and likely zoonoses hotspots [Internet]. Nairobi, Kenya: ILRI; 2012. (Report to the UK Department for International Development). Report No: Zoonoses Project 4. Available from: https://hdl.handle.net/10568/21161

9. McDermott JJ, Arimi SM. Brucellosis in sub-Saharan Africa: epidemiology, control and impact. Vet Microbiol. 2002;90(1-4):111-34.

10. Waghela S, Karstad L. Antibodies to Brucella spp. among blue wildebeest and African buffalo in Kenya. J Wildl Dis. 1986;22:189-92.

11. Motsi T, Tichiwangana S, Matope G, Mukarati N. A serological survey of brucellosis in wild ungulate species from five game parks in Zimbabwe. Onderstepoort J Vet Res. 2013;80:586.

12. Assenga JA, Matemba LE, Muller SK, Malakalinga JJ, Kazwala RR. Epidemiology of Brucella infection in the human, livestock and wildlife interface in the Katavi-Rukwa ecosystem. Tanzania. BMC Vet Res. 2015;11: 189.

13. Alexander KA, Blackburn JK, Vandewalle ME, Pesapane R, Baipoledi EK, Elzer $\mathrm{PH}$. Buffalo, Bush Meat, and the Zoonotic Threat of Brucellosis in Botswana. Plos One. 2012;7(3):e32842.

14. Kansiime C, Rutebemberwa E, Asiimwe BB, Makumbi F, Bazira J, Mugisha A. Annual trends of human brucellosis in pastoralist communities of southwestern Uganda: a retrospective ten-year study. Infect Dis Poverty. 2015:4: 39.

15. Tumwine G, Matovu E, Kabasa J, Owiny D, Majalija S. Human brucellosis: sero-prevalence and associated risk factors in agro-pastoral communities of Kiboga District Central Uganda. BMC Public Health. 2015;15:900.

16. Nasinyama G, Ssekawojwa E, Opuda J, Grimaud P, Etter E, Bellinguez A. Brucella sero-prevalence and modifiable risk factors among predisposed cattle keepers and consumers of un-pasteurized milk in Mbarara and Kampala districts. Uganda. Afr Health Sci. 2014;14(4):790-6.

17. Mugizi DR, Boqvist S, Nasinyama GW, Waiswa C, Ikwap K, Rock K, et al. Prevalence of and factors associated with Brucella sero-positivity in cattle in urban and peri-urban Gulu and Soroti towns of Uganda. J Vet Med Sci. 2015;77(5):557-64 2015/02/14 ed.

18. Kateete DP, Kabugo U, Baluku H, Nyakarahuka L, Kyobe $S$, Okee M, et al. Prevalence and antimicrobial susceptibility patterns of bacteria from milkmen and cows with clinical mastitis in and around Kampala, Uganda. Plos One. 2013;8(5):e63413.

19. Kalema-Zikusoka G, Bengis R, Michel A, Woodford MH. A preliminary investigation of tuberculosis and other diseases in African buffalo (Syncerus caffer) in Queen Elizabeth National Park, Uganda. Onderstepoort J Vet Res. 2005;72:145-51.

20. Bernard F, Vincent C, Matthieu L, David R, James D. Tuberculosis and brucellosis prevalence survey on dairy cattle in Mbarara milk basin (Uganda). Prev Vet Med. 2005;67(4):267-81.

21. Moreto W, Lemieux A. Poaching in Uganda: Perspectives of Law Enforcement Rangers. Deviant Behav. 2015;36:1-21.

22. Otto A. Baboon Meat Sold Along Major Highways - UWA. 2016 Oct 18 [cited 2020 Jun 11]; Available from: https://ugandaradionetwork.com/story/ uwa-warns-travelers-against-buying-baboon-as-game-meat-

23. Godfroid J, Garin-Bastuji B, Saegerman C, Blasco JM. Brucellosis in terrestrial wildlife. Rev Sci Tech Int Off Epizoot. 2013;32(1):27-42.

24. Makita K, Fèvre EM, Waiswa C, Eisler MC, Thrusfield M, Welburn SC. Herd prevalence of bovine brucellosis and analysis of risk factors in cattle in urban and peri-urban areas of the Kampala economic zone, Uganda. BMC Vet Res. 2011;7:60.

25. Ducrotoy MJ, Ammary K, Ait Lbacha H, Zouagui Z, Mick V, Prevost L, et al. Narrative overview of animal and human brucellosis in Morocco: intensification of livestock production as a driver for emergence? Infect Dis Poverty. 2015:4(1):57 
26. Daszak $P$, Cunningham AA, Hyatt AD. Emerging infectious diseases of wildlife--threats to biodiversity and human health. Science. 2000;287(5452): 443-9.

27. Lolli C, Marenzoni ML, Strona P, Lappo PG, Etiang P, Diverio S. Infections and risk factors for livestock with species of Anaplasma, Babesia and Brucella under semi-nomadic rearing in Karamoja Region, Uganda. Trop Anim Health Prod. 2016;48(3):603-11.

28. Bevan J. Crisis in Karamoja: armed violence and the failure of disarmament in Uganda's most deprived region, Small Arms Survey. [Internet]. Small Arms Survey, Graduate Institute of International and Development Studies, Geneva 2008; 2008 [cited 2020 Jun 11]. Available from: http://www.smalla rmssurvey.org/fileadmin/docs/B-Occasional-papers/SAS-OP21-Karamoja.pdf

29. Gradé J, Tabuti J, Van Damme P. Ethnoveterinary knowledge in pastoral Karamoja, Uganda. J Ethnopharmacol. 2009;122(2):273-93.

30. Birner R, Cohen M, llukor J, Muhumuza T, Schindler K, Mulligan S. Rebuilding agricultural livelihoods in post-conflict situations: What are the governance challenges? The case of northern Uganda. Unpubl Proj Rep Wash DC IFPRI. 2010;

31. Dobson A, Meagher M. The Population Dynamics of Brucellosis in the Yellowstone National Park. Ecology. 1996;77(4):1026-36.

32. Al-Majali AM, Talafha AQ, Ababneh MM, Ababneh MM. Seroprevalence and risk factors for bovine brucellosis in Jordan. J Vet Sci. 2009;10(1):61-5.

33. Hayward MW, Kerley GIH. Prey preferences of the lion (Panthera leo). J Zool. 2005;267(3):309-22.

34. Welburn S, Picozzi K, Coleman P, Packer C. Patterns in Age-Seroprevalence Consistent with Acquired Immunity against Trypanosoma brucei in Serengeti Lions. PLoS Negl Trop Dis. 2008;2:e347.

35. Muma JB, Munyeme M, Matope G, Siamudaala VM, Munang'andu HM, Matandiko W, et al. Brucella seroprevalence of the Kafue lechwe (Kobus leche kafuensis) and Black lechwe (Kobus leche smithemani): exposure associated to contact with cattle. Prev Vet Med. 2011;100(3-4):256-60.

36. Wilkie D, Carpenter JF. Bushmeat hunting in the Congo Basin: an assessment of impacts and options for mitigation. Biodivers Conserv. 2004;8: 927-55

37. Ndibalema VG, Songorwa AN. Illegal meat hunting in serengeti: dynamics in consumption and preferences. Afr J Ecol. 2008:46(3):311-9.

38. Gomo C, de Garine-Wichatitsky M, Caron A, Pfukenyi DM. Survey of brucellosis at the wildlife-livestock interface on the Zimbabwean side of the Great Limpopo Transfrontier Conservation Area. Trop Anim Health Prod. 2012:44(1):77-85.

39. UWA. National Giraffe Conservation Strategy and Action Plan for Uganda (2020-2030). Kampala, Uganda: Uganda Wildlife Authority (UWA); 2020.

40. Tumusiime D, Eilu G, Tweheyo M, Babweteera F. Wildlife Snaring in Budongo Forest Reserve, Uganda. Hum Dimens Wildl. 2010;15:129-44.

41. Tamil Nadu Veterinary and Animal Sciences University, Chennai- 51, India, Karthik K, Prabakar G, Indian Veterinary Research Institute, Izatnagar, Bareilly, U.P., India, Bharathi R, Tamil Nadu Veterinary and Animal Sciences University, Chennai- 51, India, et al. Equine brucellosis: Review on epidemiology, pathogenesis, clinical signs, prevention and control. J Exp Biol Agric Sci [Internet]. 2016 Dec 3 [cited 2018 Aug 29];4(Spl-4-EHIDZ):S151-60. Available from: http://jebas.org/Jou.Exp.Bio.Agr.Sci/Spl.Issue.EHIDZ16/10.18006_2016.4 (Spl-4-EHIDZ).S151.S160.pdf.

42. Condy J, Vickers D. Brucellosis in rhodesian wildlife. J S Afr Vet Assoc. 1972; 43(2):175-9

43. WCS. Nationally Threatened Species for Uganda "National Red List for Uganda for the following Taxa: Mammals, Birds, Reptiles, Amphibians, Butterflies, Dragonflies and Vascular Plants" [Internet]. Kampala, Uganda; 2016 Jan [cited 2020 Jul 11]. Available from: http://www.nationalredlist.org/ files/2016/03/National-Redlist-for-Uganda.pdf

44. Wambwa E, Manyibe T, Litoroh M, Gakuya F, Kanyingi J. Resolving humanelephant conflict in Luwero District, Uganda, through elephant translocation. Pachyderm. 2001;31:58-62.

45. UWA. UWA begins translocation of 20 Giraffes to South Bank of Murchsion Falls National Park [Internet]. Kampala, Uganda; 2016 [cited 2020 Jun 11]. Available from: https://www.ugandawildlife.org/news-events/news/uwabegins-translocation-of-20-giraffes-to-south-bank-of-mfnp

46. Caron A, Cornelis D, Foggin C, Hofmeyr M, de Garine-Wichatitsky M. African Buffalo Movement and Zoonotic Disease Risk across Transfrontier Conservation Areas. Southern Africa. Emerg Infect Dis. 2016;22(2):277-80.

47. Kock RA, Woodford MH, Rossiter PB. Disease risks associated with the translocation of wildlife. Rev Sci Tech Int Off Epizoot. 2010;29(2):329-50.
48. Stallknecht DE. Impediments to wildlife disease surveillance, research, and diagnostics. Curr Top Microbiol Immunol. 2007:315:445-61.

49. Gorsich EE, Bengis RG, Ezenwa VO, Jolles AE. Evaluation of the sensitivity and specificity of an enzyme-linked immunosorbent assay for diagnosing brucellosis in African buffalo (Syncerus caffer). J Wildl Dis. 2015;51(1):9-18.

50. Greenfield RA, Drevets DA, Machado LJ, Voskuhl GW, Cornea P, Bronze MS. Bacterial pathogens as biological weapons and agents of bioterrorism. Am J Med Sci. 2002;323(6):299-315.

51. Sekamatte M, Krishnasamy V, Bulage L, Kihembo C, Nantima N, Monje F, et al. Multisectoral prioritization of zoonotic diseases in Uganda, 2017: A One Health perspective. PloS One. 2018;13(5):e0196799.

52. NEMA. National Biodiversity Strategy and Action Plan (2015-2025): Supporting Transition to a Middle Income Status and Delivery of Sustainable Goals [Internet]. Kampala, Uganda; 2016 Jan [cited 2020 Jul 11]. Available from: https://nema.go.ug/sites/all/themes/nema/docs/NBSAP\%2 OUganda\%202015\%20-\%20Re-designed.pdf

53. Kock M, Burroughs R. Chemical and physical restraint of wild animals: a training and field manual for African species. Greyton: IWVS; 2012.

54. Bush M, Grobler D, Raath J. The Art and Science of Giraffe (Giraffa camilopardalis) Immobilization/Anesthesia by M. Bush, D.CG. Grobler and J. P. Raath; B0169.0102. In 2002.

55. OIE. OIE Terrestrial Manual - Brucellosis [Internet]. 2019 [cited 2020 Jun 11] Available from: http://www.oie.int/fileadmin/Home/eng/Health_standards/ta hm/3.01.04_BRUCELLOSIS.pdf

\section{Publisher's Note}

Springer Nature remains neutral with regard to jurisdictional claims in published maps and institutional affiliations.
Ready to submit your research? Choose BMC and benefit from:

- fast, convenient online submission

- thorough peer review by experienced researchers in your field

- rapid publication on acceptance

- support for research data, including large and complex data types

- gold Open Access which fosters wider collaboration and increased citations

- maximum visibility for your research: over $100 \mathrm{M}$ website views per year

At $\mathrm{BMC}$, research is always in progress.

Learn more biomedcentral.com/submissions 